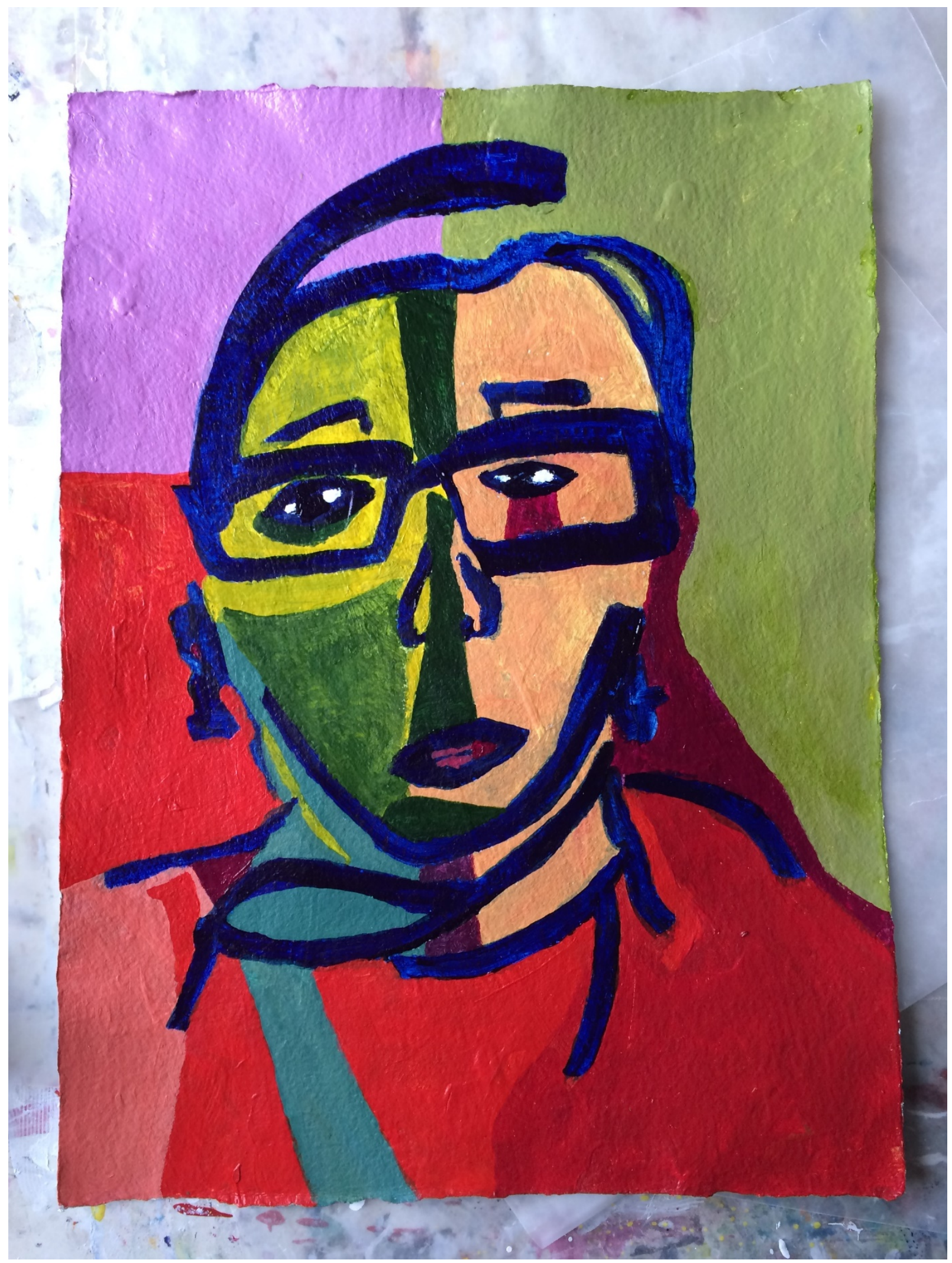

\title{
"Self Portrait"
}

Cultural and Pedagogical Inquiry, Summer 2018, 10(1), p. 122

ISSN 1916-3460 (C) 2018 University of Alberta

http://eiournals.library.ualberta.ca/index.php/cpi/index 